\title{
Management of Alternaria Blight through Genotypes, Fungicides, Bio-Agents and Botanical in Rapeseed-Mustard
}

\author{
H.K. Singh ${ }^{1 *}$, Jay Kumar $\operatorname{Yadav}^{1}$, Manish Kumar Maurya ${ }^{1}$ and S.K. Singh ${ }^{2}$ \\ ${ }^{1}$ Department Plant Pathology, Narendra Deva University of Agriculture and Technology, \\ Kumarganj, Faizabad-224229 (U.P.), India \\ ${ }^{2}$ Crop Research Station Tissuhi, Mirzapur-231001 (U. P.), India \\ *Corresponding author
}

\section{Keywords \\ Rapeseed and mustard, Alternaria blight, Management \\ Article Info \\ Accepted: \\ 20 January 2018 \\ Available Online: \\ 10 February 2018}

A B S T R A C T

Alternaria blight caused by Alternaria brassicae (Berk) Sacc. and A. brassicicola (Schw) Wiltshire is one of the most common and destructive disease of rapeseedmustard. The experiments were conducted under field condition to develop effective management strategies for this disease through evaluation of genotypes for resistance and application of fungicide, bio-agents and botanical. Out of 200 promising genotypes evaluated for resistance, none of the entry was found resistant, twenty two genotypes namely DLSC-1, DRMR-261, DRMR-270, GSC-101, GSL-1, NPC-20 and PHR-2, CNH-11-13, CNH-11-7, EC-552608, HNS-1001, PAB 04-10, PAB 05-16, PAB 05-19, PAB 09-05, PAB-2004-4, PAB-2005-16, PPBJ 5, PPBJ-2, PPBJ-3, PPBN 3 and PPBN-2 were moderately resistant and 63 genotypes moderately susceptible. Seed treatment with Apron @ 6g/Kg seed and spray of all fungicides, bio-agents and botanical extract, significantly reduced the blight severity in comparison to the untreated control (water spray). Of the fungicides, Nativo@ 0.05\% was found most effective followed by Difenconazole@0.05\%, Iprodione@0.2, Folicure@0.2, Difolatan@0.2, Mancozeb @0.2, Antracol@0.25,Pseudomonas fluorescens@1.0, Trichoderma harzianum @ 1.0 and Garlic bulb extract @ 1.0 which showed 8.70\%, $14.62 \%, 16.27 \%, 16.41 \%, 18.54 \%, 20.51 \%, 21.42 \%, 24.27 \%, 25.42 \%$, and $26.83 \%$, severity, respectively after third spray of each chemical, bio-agents and botanical extract. The disease severity of water spray control was $69.10 \%$. Same tread was also recorded with per cent disease control. Maximum seed yield (kg/ha) and yield increase (\%) of 1740.22, 37.90 was recorded with the treatment Nativo @ 0.05\% followed by Difenconazole @ 0.05\% (1629.61,29.16), Iprodione @ $0.2(1617.11,28.17)$, Folicure @ 0.2 (1587.50, 25.85), Trichoderma harzianum @ 1.0 (1525.68, 20.93), Difolatan @ 0.2 (1516.98, 2024), Pseudomonas fluorescens@1.0 (1512.37, 1987), Antracol @ 0.25 (1511.45,19.80), Mancozeb @ 0.2 (1507.99, 19.52), respectively. The maximum benefit cost ratio 1:12.60 was obtained with Garlic bulb extract @ 1.0 followed by Trichoderma harzianum @ 1.0 (1:6.0), Nativo@0.05\% (1:4.01), Pseudomonas flurescence@1.0 (1:3.79). 


\section{Introduction}

Rapeseed and mustard are the major oilseed crops grown in northern and eastern part of India. Alternaria blight caused by Alternaria brassicae (Berk.) Sacc and A. brassicicola (Schewein) Wiltshire, is one of the most severe disease and yield distablishing factors reduction from 35 to 70 per cent (Kolte, 1985, Saharan, 1992, Singh and Singh, 2005, Kumar et al., 2014). In addition to direct losses, the disease also affects the quality of the seed by reducing seed size; seed colour and oil content (Kaushik et al., 1984). Information on incidence of Alternaria blight on various cultivars and management of disease through different chemicals is lacking (Prasad et al., 2003). Therefore, the present investigation was undertaken to identify genotypes for resistance to Alternaria blight, chemicals, bioagents and botanical which would reduce the disease intensity.

\section{Materials and Methods}

The investigations were carried out at Genetics and Plant Breeding Research Farm and in the laboratory of the Department of Plant Pathology, N.D. University of Agriculture and Technology, Kumarganj, Faizabad $\left(26^{0} 47 \mathrm{~N}\right.$ latitude and 82.12 'E longitudes at an altitude of $113 \mathrm{~m}$ from the mean sea level). The investigations consisted of two separate components i.e. varietal screening for host resistance and management in Indian mustard [Brassica juncea (L.) Czern $\&$ Coss.] through fungicide, bio-agents and botanical.

For resistance evaluation, two hundred twenty rapeseed-mustard genotypes of diverse background were sown in single rows of 3 meter length having $30 \times 10 \mathrm{~cm}$ row to row and plant to plant, respectively and replicated twice in plot supplemented with diseased plant debris carrying Alternaria brassicae inoculum from the preceding years. A susceptible variety 'Jagrati' was planted in single row after every five test lines and flanked the trial around with triple rows to serve as infector. The crop was inoculated twice by the spore suspension $10^{-6}$ of Alternaria brassicae (Berk.) Sacc. artificially to create epiphytotic condition. The trial was given three irrigations to maintain a humid micro-climate.

The disease severity was recorded following scale as per recommendation of All India Coordinated Research Project on RapeseedMustard, 2017 which is as under [0=No lesion [Immune (I)]; 1= Non sporulating pinpoint size or small brown necrotic spots, less than $5 \%$ leaf area covered by the lesions [Highly resistant $(\mathrm{HR})]$; $3=$ small roundish slightly sporulating larger brown necrotic spot, about 1-2 $\mathrm{mm}$ in diameter with a distinct margin or yellow halo, 5-10\% leaf area covered by lesions [Resistant (R)]; $5=$ moderate sporulation, non-coalescing larger brown spots, about $2-4 \mathrm{~mm}$ in diameter with a distinct margin or yellow halo, 11-25\% leaf area covered by the lesions [Moderately resistant $(\mathrm{MR})] ; \quad 7=$ moderately sporulating, coalescing, larger brown spots about 4-5 mm in diameter, 26-50\% leaf area covered by the lesions [Susceptible (S)]; $9=$ profusely sporulating, rapidly coalescing, brown to black spots measuring more than $6 \mathrm{~mm}$ in diameter without margins covering more than $50 \%$ leaf area [Highly susceptible (HS)] and genotypes were classified based on the highest of the two years disease score.

For the management, a field experiment with twelve treatments including control was laid out with three replications and test variety 'Varuna'. The trial was sown in randomized block design (RBD) during 2012-13 and 201314 in first week of November having plant spacing of $30 \times 10 \mathrm{~cm}$ in plots size of $5 \times 3 \mathrm{~m}$ which has been identified as a hot spot for this disease. Twelve treatments having eight 
fungicides i.e Apron, Mancozeb, Difolatan, Iprodiane, Difenconazoles, Antracal, Nativo, Folicure; two bio- agents i.e. Trichoderma horzianum and Pseudomonas fluorescens; one garlic bulb extract and one check plot by water spray (control) (Table 1). The first spray was given on the initiation of disease which was followed by two subsequent spraying at 15 days intervals. Observations were recorded on leaf blight severity (0-9 disease rating scale based on blighted area) after final spray, on ten randomly selected plants from each plot and per cent disease intensity (PDI) was calculated:

PDI $=\frac{\text { Sum of total numerical ratings }}{\text { Total number of leaves observed }} \times \frac{100}{\text { Highest grade }}$

The avoidable yield loss (AYL) was also calculated by the following formula:

$\mathrm{AYL}=\frac{\mathrm{Yp}-\mathrm{Yup}}{\mathrm{Yp}} \times 100$

Where,

Yp = yield under protected conditions

Yup $=$ yield under unprotected conditions

\section{Results and Discussion}

Out of two hundred twenty genotypes, none of the entry was found resistant, twenty two genotypes namely DLSC-1, DRMR-261, DRMR-270, GSC-101, GSL-1, NPC-20 and PHR-2, CNH-11-13, CNH-11-7, EC-552608, HNS-1001, PAB 04-10, PAB 05-16, PAB 0519, PAB 09-05, PAB-2004-4, PAB-2005-16, PPBJ 5, PPBJ-2, PPBJ-3, PPBN 3 and PPBN2 were moderately resistant and 63 genotypes moderately susceptible. Rest of the genotypes was either susceptible or highly susceptible (Table 1). Dang et al., (2002), Singh and Singh (2005) and Singh et.al (2006), Singh et al., (2013), Kumar et al., (2016), Singh et al.,
(2016) also found variable level of resistance in rapeseed-mustard and did not report any immunity.

Seed treatment with Apron @ 6g/Kg seed and spray of all fungicides, bio-agents and botanical extract, significantly reduced the blight severity in comparison to the untreated control (water spray). Of the fungicides, Nativo@0.05\% was found most effective followed by Difenconazole @ 0.05\%, Iprodione @ 0.2, Folicure @ 0.2, Difolatan@ 0.2, Mancozeb @ 0.2, Antracol @ 0.25, Pseudomonas fluorescens @1.0,Trichoderma harzianum@1.0, Garlic bulb extract@1.0 and Seed treatment with Apron @ 6g/Kg seed which showed $8.70 \%, 14.62 \%, 16.27 \%$, $16.14 \%, 18.54 \%, 20.51 \%, 21.42 \%, 24.27 \%$, $25.42 \%, 26.83 \%$, and $52.40 \%$ severity, respectively after third spray of each chemical, bio-agents and botanical extract. The disease severity of water spray control was $69.10 \%$. Same tread was also recorded with per cent disease control (Table 2).

Maximum seed yield ( $\mathrm{kg} / \mathrm{ha})$ and yield increase $(\%)$ of $1740.22,37.90$ was recorded with the treatment Nativo@0.05\% followed by Difenconazole @ 0.05\% (1629.61, 29.16), Iprodione @ 0.2 (1617.11, 28.17), Folicure @ 0.2 (1587.50, 25.85), Trichoderma harzianum @ 1.0 (1525.68, 20.93), Difolatan @ 0.2 (1516.98, 2024), Pseudomonas fluorescens@ 1.0 (1512.37, 1987), Antracol @ 0.25 (1511.45,19.80), Mancozeb @ 0.2 (1507.99, 19.52), respectively.

All the treatments could avoided test weight loss of $8.52 \%$ to $27.49 \%$ and maximum with Nativo@0.05\% followed by Difenconazole @ 0.05\% (22.52), Iprodione @ 0.2 (21.98), Folicure @ 0.2 (20.54), Trichoderma harzianum @1.0 (17.30), Difolatan @ 0.2 (16.83), Garlic bulb extract @1.0 (16.70), respectively (Table 2 ). 
Table.1 Management of Alternaria blight of mustard by chemicals, bio-agents and botanical

\begin{tabular}{|c|c|c|c|c|c|c|c|c|c|c|}
\hline \multirow[t]{2}{*}{ Treatment /Doses } & \multicolumn{2}{|c|}{ Disease Intensity (\%) } & \multirow[t]{2}{*}{ Mean } & \multirow{2}{*}{$\begin{array}{l}\text { Per cent } \\
\text { disease } \\
\text { control }\end{array}$} & \multicolumn{2}{|c|}{ Yield (kg/ha) } & \multirow{2}{*}{$\begin{array}{l}\text { Mean } \\
\text { (Kg/ha) }\end{array}$} & \multirow{2}{*}{$\begin{array}{c}\text { Yield } \\
\text { Increased } \\
(\%)\end{array}$} & \multirow{2}{*}{$\begin{array}{l}\text { Avoidable } \\
\text { yield loss }\end{array}$} & \multirow{2}{*}{$\begin{array}{l}\text { Cost } \\
\text { benefit } \\
\text { ratio }\end{array}$} \\
\hline & $2012-2013$ & 2013-2014 & & & $\begin{array}{l}2012- \\
2013\end{array}$ & $\begin{array}{l}2013- \\
2014\end{array}$ & & & & \\
\hline $\begin{array}{l}\text { Seed Treatment } \\
\text { with Apron @ } \\
\text { 6g/Kg seed }\end{array}$ & $\begin{array}{c}53.07 \\
(47.12)\end{array}$ & $\begin{array}{c}51.74 \\
(46.38)\end{array}$ & 52.40 & 24.16 & 1315.53 & 1443.02 & 1379.27 & 9.32 & 8.52 & $1: 8.34$ \\
\hline $\begin{array}{l}\text { Difenconazole @ } \\
0.05 \%\end{array}$ & $\begin{array}{c}15.98 \\
(23.50)\end{array}$ & $\begin{array}{c}13.26 \\
(22.46)\end{array}$ & 14.62 & 78.84 & 1577.77 & 1681.45 & 1629.61 & 29.16 & 22.57 & $1: 1.40$ \\
\hline Antracol@0.25\% & $\begin{array}{l}22.35 \\
(28.18)\end{array}$ & $\begin{array}{c}20.49 \\
(27.56)\end{array}$ & 21.42 & 69.00 & 1465.77 & 1557.41 & 1511.45 & 19.80 & 16.52 & $1: 0.94$ \\
\hline Difolatan@ 0.2\% & $\begin{array}{c}19.90 \\
(26.49)\end{array}$ & $\begin{array}{c}17.19 \\
(25.48)\end{array}$ & 18.54 & 73.16 & 1465.57 & 1568.39 & 1516.98 & 20.24 & 16.83 & $1: 2.22$ \\
\hline Iprodione@ 0.2\% & $\begin{array}{c}17.18 \\
(24.43)\end{array}$ & $\begin{array}{c}15.36 \\
(23.73)\end{array}$ & 16.27 & 76.45 & 1565.62 & 1668.60 & 1617.11 & 28.17 & 21.98 & $1: 2.35$ \\
\hline Mancozeb@0.2\% & $\begin{array}{c}22.52 \\
(28.32)\end{array}$ & $\begin{array}{l}18.50 \\
(26.92)\end{array}$ & 20.51 & 70.31 & 1445.33 & 1570.65 & 1507.99 & 19.52 & 16.33 & $1: 1.42$ \\
\hline Nativo@0.05\% & $\begin{array}{c}7.90 \\
(16.32)\end{array}$ & $\begin{array}{c}9.50 \\
(17.16)\end{array}$ & 8.70 & 87.41 & 1700.11 & 1780.33 & 1740.22 & 37.90 & 27.49 & $1: 4.01$ \\
\hline Folicure@0.2\% & $\begin{array}{c}15.33 \\
(23.03)\end{array}$ & $\begin{array}{c}17.50 \\
(23.89)\end{array}$ & 16.41 & 76.25 & 1600.00 & 1575.00 & 1587.5 & 25.85 & 20.54 & $1: 1.20$ \\
\hline $\begin{array}{l}\text { Trichoderma } \\
\text { harzianum@1.0\% }\end{array}$ & $\begin{array}{c}25.96 \\
(30.59)\end{array}$ & $\begin{array}{c}24.88 \\
(30.26)\end{array}$ & 25.42 & 63.21 & 1455.41 & 1595.95 & 1525.68 & 20.93 & 17.30 & $1: 6.00$ \\
\hline $\begin{array}{l}\text { Pseudomonas } \\
\text { fluorescens@1.0\% }\end{array}$ & $\begin{array}{c}25.11 \\
(30.07)\end{array}$ & $\begin{array}{c}23.43 \\
(29.47)\end{array}$ & 24.27 & 64.87 & 1455.08 & 1569.62 & 1512.35 & 19.87 & 16.57 & $1: 3.79$ \\
\hline $\begin{array}{l}\text { Garlic bulb extract } \\
\text { @ } 1.0 \%\end{array}$ & $\begin{array}{c}27.92 \\
(31.88)\end{array}$ & $\begin{array}{c}25.74 \\
(31.18)\end{array}$ & 26.83 & 61.17 & 1459.44 & 1569.94 & 1514.69 & 20.05 & 16.70 & $1: 12.6$ \\
\hline $\begin{array}{l}\text { Control (Water } \\
\text { spray) }\end{array}$ & $\begin{array}{c}71.14 \\
(57.48)\end{array}$ & $\begin{array}{c}67.05 \\
(56.73)\end{array}$ & 69.10 & - & 1256.67 & 1266.67 & 1261.67 & & 0.00 & $1: 8.34$ \\
\hline $\operatorname{SEm} \pm$ & 1.20 & 1.1. & & & 20.25 & 14.83 & & & & \\
\hline CD at $5 \%$ & 2.75 & 2.50 & & & 49.84 & 41.53 & & & & \\
\hline
\end{tabular}


Table.2 Reaction of rapeseed and mustard genotypes against Alternaria blight on the basis of maximum grade

\begin{tabular}{|c|c|c|c|}
\hline $\begin{array}{l}\text { Maximum } \\
\text { Grade }(0-9)\end{array}$ & Reactions & $\begin{array}{l}\text { No. of } \\
\text { Genotypes }\end{array}$ & Name of genotypes \\
\hline 0 & $\mathbf{F}$ & None & - \\
\hline 1 & HR & None & - \\
\hline 3 & $\mathbf{R}$ & None & \\
\hline 5 & MR & 22 & $\begin{array}{l}\text { DLSC-1, DRMR-261, DRMR-270, GSC-101, GSL-1, NPC-20 and PHR-2, CNH-11-13, } \\
\text { CNH-11-7, EC-552608, HNS-1001, PAB 04-10, PAB 05-16, PAB 05-19, PAB 09-05, PAB- } \\
\text { 2004-4, PAB-2005-16, PPBJ 5, PPBJ-2, PPBJ-3, PPBN } 3 \text { and PPBN-2 }\end{array}$ \\
\hline 7 & MS & 63 & $\begin{array}{l}\text { 44S31, AHS-55, C-3001-1-1-1, DRMR-100, DRMR-11-08, DRMR-11-10, DRMR-11-11, } \\
\text { DRMR-1187-60, DRMR-13, DRMR-302, DRMR-92, DRMRIJ-04, DRMRIJ-11-04, } \\
\text { DRMRIJ-11-286, DRMRIJ-27, DRMRMJA-35, DRMRMJB-38, EC-399299, EC-414324, } \\
\text { Hyb-7-2011, IC-255498, IC-399678, JMT-08-13, KMR(L)-12-1, KMR(L)-12-2, LADL, } \\
\text { LES-45, MCP-807, NPJ 156, NPJ-164, NPJ-167, NPJ-168, NPJ-169, NPJ-171, NUDH-YJ-6, } \\
\text { OMK-4, PMH-12-2, PMH-12-3, PPBJ 4, PR-2006-14, PR-2008-1, PR-2009-12, PRB-2004- } \\
\text { 3-4, PRB-2008-5, PRL-2010-10, PRO-5111, RAUDT-10-33, RB-59, RB-64, RGN-306, } \\
\text { RGN-315, RGN-323, RH-0831, RH0901, RH0948, RH-0952, RMM-9-12, RMWR-09-4, } \\
\text { RMWR-09-5, RMWR-09-6, RRN-813, SKM-1013 and SKM-B-817 }\end{array}$ \\
\hline 9 & $\mathbf{S}$ & 115 & $\begin{array}{l}\text { 2IJ 0009, 45S42, AH-53, Albeli-1, ASH 42, CJ-37-61, CS 13000-3-3-2-2-1, CS-1100-1-2-2- } \\
\text { 3, CS-204-2-2-1, Divya-33, DRMR-10-40, DRMR-15, DRMR-1679-100, DRMR-312, } \\
\text { DRMR-316, DRMR-64, DRMR-81, DRMRHJ-2409, DRMRIJ-11-287, DRMRIJ-1-275, } \\
\text { DRMRIJ-21-1, DRMRIJ-31, DRMRMJA-27, EC 399301, EC-414322, Hyb-9-2011, IC- } \\
\text { 399824, JC-210-541, JMM-08-1, JMWR-08-3, KMR-12-1, KMR-12-2, LES-46, LES-47, } \\
\text { MCP-802, NDRE-7, NDRS 2017, NPJ 153, NPJ 154, NPJ 155, NPJ-121, NPJ-127, NPJ-140, } \\
\text { NPJ-165, NPJ-170, NPJ-172, NPJ-173, NPJ-174, NPJ-175, NUDH-YJ-10, PAB 09-07, PBR- } \\
\text { 384, PBR-422, PMH-12-1, PPBR-2, PRB-2008-5, PRE-2007-6, PRE-2010-15, PRE-2010-19, } \\
\text { PRL-2009-3, PT-2006-4, PT-2008-2, PT-2010-10, PT-303, PTE-2008-02, PYS-2007-10, } \\
\text { PYS-2008-5, RAUDT-10-18, RAUDYS-10-07, RAUDYS-10-12, RAURD 09-25, RAURD- } \\
\text { 9-78, RAURD-09-212, RAURD-09-32, RAURDL-02-01, RB-57, RGN-307, RGN-308, R- R- R-1101, RMM- } \\
\text { RGN-321, RH 0749, RH-0555A, RH-0834, RH0902, RH-0904, RH-903, RHH-1101, } \\
\text { 10-1, RMM-10-12, RMM-9-4, RMT-08-2, RMT-10-10, RMT-10-7, Rohini, RRN-783, RRN- } \\
\text { 788, RRN-789, RTM-10-10, RTM-1351, RTM-1359, SKM-1040, SKM-815, TK-17-14, } \\
\text { TKM-102, TL-21, TM-106, TM-117, Varuna, YSB-9, YSKM-12-1, YSKM-12-2, YSWB- } \\
\text { 2010/8, YSWB-2011-10-1, YSWB-2012/9, YSWB-2014/3-12 and YSWB-20229/2-12 }\end{array}$ \\
\hline
\end{tabular}


The maximum benefit cost ratio 1:12.60 was obtained with Garlic bulb extract@1.0 followed by Trichoderma harzianum @ 1.0 (1:6.0), Nativo @ $0.05 \%$ (1:4.01), Pseudomonas fluorescens @ 1.0 (1:3.79). Singh et al., (2016) have reported Garlic bulb extract@1.0 and Trichoderma harzianum @ 1.0 as most economic as compared to others which supports the present findings. The maximum cost benefit cost ratio (1:21.83) was also reported (Mahapatra and Das, 2016) only single application of Garlic bulb extract which is highly acceptable for eco-friendly management of Alternaria blight of mustard. Nativo $0.05 \%$ was found most effective or reduction of disease and enhance the yield but ranked $3^{\text {rd }}$ in benefit cost ratio (Table 2). It is due to its high cost value and may be due to higher doses.

It is evident from the results that all the fungicides and chemicals were found effective however; maximum control was obtained by the application of $0.05 \%$ Nativo followed by Difenconazole @ 0.05\%.Among the bio pesticide, best control was obtained by application of garlic bulb extracts @ 1\% followed by Trichoderma harzianum @1.0\%. The variable results of fungicides and botanicals in reduction of disease severity of Alternaria blight may be attributed to the toxic principles present in the fungicides and botanicals. The efficacy of botanicals, biocontrol agent (Garlic bulb extract, Neem, Eucalyptus, Madar Dhatura and Trichoderma harzianum) and with fungicides in management of Altenaria blight of rapeseedmustard was also reported by other workers (Meena et al., 2008; Yadav, 2009; Patni et al., 2005, Singh et al., 2013; Singh et al., 2016; Kumar et al., 2016).

\section{References}

Dang, J.K., Sangwan, M.S., Mehta, M. and Kaushik, C.D. (2000). Multiple disease resistance against four fungal diseases of rapeseed mustard. Indian Phytopath. 53 (3): 455-458

Kaushik, C.D.; Saharan, G.S. and Kaushik, J.C. (1984). Magnitude of losses in yield and management of Alternaria blight in rapessed-mustard. Indian Phytopath., 37 (2): 398.

Kolte, S.J. (1985). Disease of Annual Edible Oilseed Crops. Volume II RapeseedMustard and Sesame Disease. C.R.C. Press. Inc. Boca. Raton, Florida pp. 135.

Kolte, S.J. (2002). Diseases and their management in oilseed crops, new paradigm in oilseeds and oil: research and development needs (Raimangla, Harvir Singh, D.M. Hegde ed.) Indian Society of Oilseeds Research, Hyderabad, India, 244-252.

Kumar, D., Bharati, Y. K., Singh, S.K. and Singh, H.K. (2016). Evaluation of plant protection chemicals and botanicals for management of Alternaria blight in yellow sarson (Brassica campestris). Indian Phytopath. 69 (4s) 319-325.

Kumar, H., Singh, H. K., Singh, R. K. and Mishra P. (2014). Yield loss assessment due to Alternaria blight in Indian mustard [Brassica juncea (L.) Czern \& Coss.]. International Journal of Agricultural and Statistical Sciences 10 (1): 299-302.

Kumar, H., Singh, H. K., Singh, R. K. and Mishra P. (2014). Yield loss assessment due to Alternaria blight in Indian mustard [Brassica juncea (L.) Czern \& Coss.]. International J. Agril and Stat. Sci. 10 (1): 299-302.

Mahapatra, S. and Das, S. (2016). Spraying schedule of garlic bulb extract, mancozeb and salicyclic acid against Alternaria blight of mustard. Indian Phytoph. 69 (4): 419-421.

Meena, P.D., Chattopadhyay, C. and Meena, R.L. (2008). Ecofriendly management 
of Alternaria blight in Brassica juncea. Indian Phytopath. 61(1): 65-69.

Patni, C.S., Kolte, S.J. and Awasthi, R.P. (2005). Efficacy of botanicals against Alternaria blight (Alternaria brassicae) of mustard. Indian Phytopath. 58(4): 426-430.

Prasad, R.; Saxena, D. and Chandra, S. (2003). Yield losses by Alternaria blight in promising genotypes of Indian mustard. Indian Phytopatology, 56 (2): 205-206.

Saharan, G.S. (1992). Management of rapeseed and mustard diseases, Advances in Oilseed Research Vol. I. Rapeseed mustard (Eds. Kumar, D. and Rai, M.) pp 151-188. Scientific Publishers, 15 A, New Pali Road, Jodhpur, India 400pp.

Singh, H. K., Srivastava, S., Singh, R.B. and Singh, A.K. (2013). Management of
Alternaria blight of rapeseed-mustard. $J$. Pl. Dis. Sci. 8 (2): 131-136.

Singh, H.K. and Singh, R.B. and Bhajan, R (2006). Identification of resistance source against Alternaria blight of rapeseed mustard. Indian Phytopath.59 (3): 385.

Singh, H.K. and Singh, R.B. and Maurya, K.N. (2016). Management of major fungal foliar diseases of rapeseedmustard. Res. on Crops. 16 (1): 182188.

Singh, R.B. and Singh, R.N. (2005). Status and management of foliar diseases of timely sown mustard in mid-eastern India. Pl. Dis. Res., 20 (1): 18-24.

Yadav, M.S. (2009). Bio-pesticidal effect of botanicals on the management of mustard diseases. Indian Phytopath. 62(4): 488-492.

\section{How to cite this article:}

Singh, H.K., Jay Kumar Yadav, Manish Kumar Maurya and Singh, S.K. 2018. Management of Alternaria Blight through Genotypes, Fungicides, Bio-Agents and Botanical in RapeseedMustard. Int.J.Curr.Microbiol.App.Sci. 7(02): 2463-2469.

doi: https://doi.org/10.20546/ijcmas.2018.702.300 